\title{
Environmental stress and epigenetic transgenerational inheritance
}

\author{
Michael K Skinner
}

\begin{abstract}
Previous studies have shown a wide variety of environmental toxicants and abnormal nutrition can promote the epigenetic transgenerational inheritance of disease. More recently a number of studies have indicated environmental stress can also promote epigenetic alterations that are transmitted to subsequent generations to induce pathologies. A recent study by Yao and colleagues demonstrated gestational exposure to restraint stress and forced swimming promoted preterm birth risk and adverse newborn outcomes generationally. This ancestral stress promoted the epigenetic transgenerational inheritance of abnormalities in the great-grand offspring of the exposed gestating female. Several studies now support the role of environmental stress in promoting the epigenetic transgenerational inheritance of disease. Observations suggest ancestral environmental stress may be a component of disease etiology in the current population.
\end{abstract}

Please see related article: http://www.biomedcentral.com/content/pdf/s12916-014-0121-6.pdf.

Keywords: Epigenetic, Non-genetic inheritance, Stress, Transgenerational

\section{Background}

The ability of environmental factors, such as stress [1], to promote the epigenetic transgenerational inheritance of disease and phenotypic variation has now been established in a number of organisms ranging from plants to humans, with a variety of environmental exposures [2]. One of the first studies found that environmental toxicants such as fungicides and pesticides promoted epigenetic transgenerational inheritance of reproductive disease [3]. Subsequently a large number of different types of toxicants (plastics, hydrocarbons, dioxin, biocides, dichlorodiphenyltrichloroethane (DDT)) have been shown to promote the transgenerational inheritance of disease [4] from obesity to cancer [5] (Table 1). Other critical environmental factors found to promote transgenerational disease are nutritional abnormalities such as caloric restriction or high fat diets [6]. In species such as insects and plants both drought and temperature have also been shown to be critical environmental factors $[7,8]$ (Table 1). Therefore, a large number of environmental factors have been shown to promote the epigenetic transgenerational

Correspondence: skinner@wsu.edu

Center for Reproductive Biology, School of Biological Sciences, Washington

State University, Pullman, WA 99164-4236, USA inheritance of disease or phenotypic variation in a variety of different species, including humans [9]. This environmentally induced form of non-genetic inheritance will have a significant impact on disease etiology $[2,10]$ and areas of biology such as evolution [11].

Epigenetic transgenerational inheritance is defined as 'the germline (egg or sperm) transmission of epigenetic information between generations in the absence of any environmental exposure' [10]. Direct environmental exposure does not involve a generational phenotype, only direct toxicity or physiological effects of the individual exposed [2]. As previously described [2,32], the exposure of an individual any time during development (F0 generation) results in the exposure of that individual and the germline (sperm or egg) that will generate the next generation (F1 generation) (Figure 1). The exposure of a gestating female exposed the F0 generation female, F1 generation fetus and germline that will generate the F2 generation (Figure 1). The ability of an exposure to act on multiple generations is termed a multigenerational exposure [32]. Where direct exposure is involved, no transgenerational effects are observed. Unfortunately, many 
Table 1 Examples of transgenerational inheritance studies

\begin{tabular}{|c|c|c|}
\hline Exposure & Pathology & Reference \\
\hline \multicolumn{3}{|l|}{ Toxicants } \\
\hline \multirow[t]{3}{*}{ Vinclozolin } & Testis, prostate, kidney disease, tumors, immune & Anway et al., 2005 [3]; 2006 [12] \\
\hline & Gender-specific changes in anxiety-like behavior & Skinner et al., 2008 [13] \\
\hline & Immune and reproductive & Nilsson et al., 2008 [14] \\
\hline Methoxychlor & Testis, kidney, ovary, obesity & Anway et al., 2005 [3], Manikkam et al. 2014 [15] \\
\hline Permethrin/DEET & Prostate, kidney disease & Manikkam et al. 2012 [16] \\
\hline Dioxin & Prostate, kidney, fertility, pregnancy & Manikkam et al. 2012 [17] Bruner-Tran et al. 2011 [18] \\
\hline BPA/phthalates & Prostate, kidney, obesity & Manikkam et al. 2013 [19] \\
\hline Hydrocarbon mixture (jet fuel) & Prostate, kidney, obesity, immune and reproduction & Tracey et al. 2013 [20] \\
\hline $\begin{array}{l}\text { Vinclozolin, permethrin/DEET, } \\
\text { plastics, dioxin, jet fuel }\end{array}$ & Polycystic ovaries, reduced primordial follicle pool & Nilsson et al. 2012 [21] \\
\hline DDT & Obesity, kidney, testis & Skinner et al. 2013 [5] \\
\hline Phthalate & Testis and spermatogonial stem cell & Doyle et al. 2013 [22] \\
\hline Tributyltin & Obesity and adipose cell & Chamorro-Garcia et al. 2013 [23] \\
\hline BPA & Social behavior, implantation, litter size, sperm & Wolstenholme et al. 2012 [24]; Salian et al. 2009 [25] \\
\hline \multicolumn{3}{|l|}{ Others } \\
\hline Caloric restriction & Cardiovascular mortality & Bygren et al. 2014 [26] \\
\hline High fat diet & Growth and insulin sensitivity & Dunn and Bale 2011 [6] \\
\hline Folate & Congenital malformations & Padmanabhan et al. 2013 [27] \\
\hline Drought & DNA methylation changes & Zheng et al. 2013 [7] \\
\hline Heat/salt & Flowering and salt tolerance & Suter and Widmer 2013 [28] \\
\hline Prediabetes & Glucose tolerance and insulin sensitivity & Wei et al. 2014 [29] \\
\hline Smoking & Abnormal pulmonary function & Rehan et al. 2013 [30] \\
\hline Alcohol & Endocrine and neuronal function & Govorko et al. 2012 [31] \\
\hline Heat stress & Increased Hsp70 production and tolerance to heat stress & Norouzitallab et al. 2014 [8] \\
\hline
\end{tabular}

BPA, Bisphenol A; DEET, N,N-diethyl-m-toluamide.

studies have misused the term transgenerational to refer to multigenerational exposure effects. By contrast, if studies are extending to generations with no direct environmental exposure then observed effects can be considered transgenerational because the germline is the only cell type able to transmit epigenetic information generationally (Figure 1).

Epigenetics is defined as 'molecular factors/processes around DNA that regulates genome activity independent of DNA, and that are mitotically stable' [10]. The types

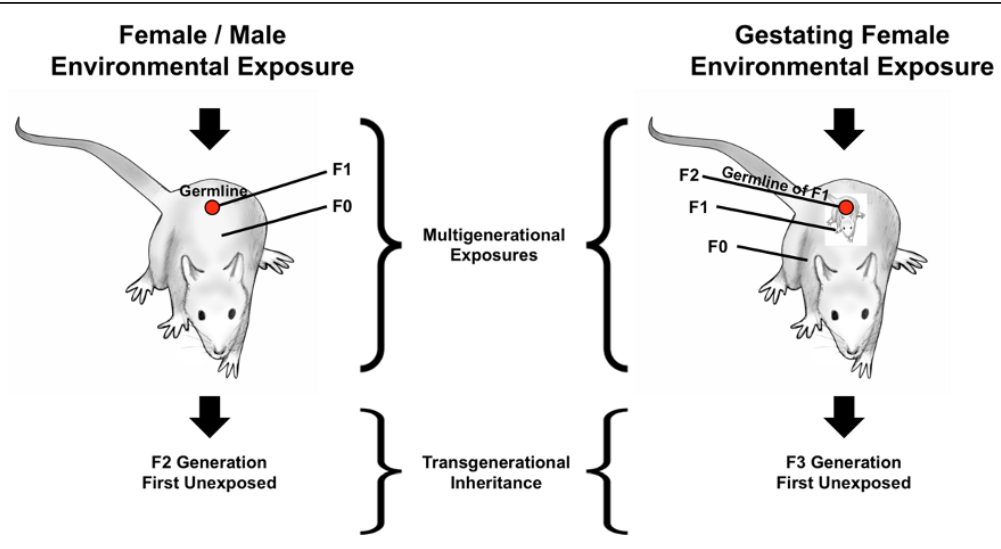

Figure 1 Schematic of multigenerational exposure and transgenerational inheritance. 
of molecular processes involved are DNA methylation, histone modifications, chromatin structure, and noncoding RNA (ncRNA). The best characterized epigenetic factor to be involved in germline transmission of epigenetic information is DNA methylation. An example is imprinted genes that mediate paternal or maternal allelic transmission of specific DNA methylation patterns [33]. A number of studies have shown that environmentally induced epigenetic transgenerational inheritance involves altered germline DNA methylation [4,34]. More recently ncRNA has been suggested as an additional mechanism in germline transmission of epigenetic information [35]. Histone modifications have also been suggested in a variety of organisms [36]. Although DNA methylation has a critical role in fetal germline development and early embryonic development [37], all the epigenetic processes will likely be involved and have unique functions in regulating development [10]. Further studies regarding the role of all epigenetic processes in environmentally induced epigenetic transgenerational inheritance are required.

\section{Environmental stress and transgenerational phenotypes}

A number of studies have shown multigenerational effects of stress [38]. One of the best initial examples was the work of Suderman and colleagues [39] showing the generational effects of maternal care on early postnatal life. Optimal early postnatal maternal care promoted epigenetic programming of the brain that created an adult female with good maternal care characteristics, which then passed on to subsequent generations. By contrast, bad early postnatal maternal care (environmental stress) promoted bad maternal characteristics later in life and altered epigenetic programming of the brain to propagate bad maternal care generationally [39]. This is a good example of an environmental exposure at each generation promoting epigenetic programming that leads to a specific phenotype in the individual, that is, a multigenerational exposure [32]. Other examples of multigenerational exposures influenced by stress have also been described [40-42]. Environmentally altered epigenetics is the critical molecular mechanism for these multigenerational exposures [32]. Somatic cell epigenetic effects will be the most predominant environmental impacts on an individual's phenotype and disease. If these effects do not involve the germline, they will not be transmitted to subsequent generations.

One of the initial studies to demonstrate environmental stress promoting the epigenetic transgenerational inheritance of disease was a three-generation study involving maternal separation and maternal restraint stress [43]. Social abilities and brain function showed transgenerational alteration in the F2 and F3 generations. A recent study investigated the ability of a paternal olfactory stress experience to promote the transgenerational inheritance of an olfactory stress response in F2 generation progeny [44]. Correlations with DNA methylation patterns in the olfactory receptor system were documented in the transgenerational offspring. Although a limited number of transgenerational stress-induced pathologies have been observed (Table 2), there have been reviews on the topic $[38,45]$.

In addition to the ability of ancestral stress to induce the epigenetic transgenerational inheritance of disease, a previous study demonstrated altered stress responses in transgenerational individuals [46]. Toxicant (vinclozolin) lineage transgenerational (F3 generation) rats were found to have altered stress responses (adolescence restraint stress) later in life. These stress responses were sex specific and gene expression networks in brain regions were found to correlate with these transgenerational stress responses [47]. Therefore, stress can induce the transgenerational inheritance of disease, and ancestral exposures to a variety of factors can alter stress response transgenerationally.

\section{Ancestral stress exposure promotes preterm birth and newborn abnormalities}

Yao and colleagues [1] designed a study to investigate the ability of environmental stress to promote the epigenetic transgenerational inheritance of disease. The experimental design exposed a gestating female to restraint stress and forced swimming in the later stages of fetal development. The offspring (F1 generation) were bred to generate F2 and F3 generations. A non-stress control lineage, stress lineage (only F0 generation female stress) and chronic stress lineage (all generations stressed) were examined for preterm birth and newborn abnormalities. The F3 generation stress lineage animals had decreased pup weights and altered developmental behaviors. The gestational length progressively declined with each generation leading to a higher preterm birth risk. The F2 generation brain and uterus expression of ncRNA for selected miRNA were altered. Therefore, the study demonstrated that gestational stress promoted the epigenetic transgenerational inheritance of preterm birth risk

\begin{tabular}{lll}
$\begin{array}{l}\text { Table } \mathbf{2} \text { Stress-induced transgenerational inheritance of } \\
\text { pathologies }\end{array}$ & \\
\hline Stress exposure & Pathology & Reference \\
\hline $\begin{array}{l}\text { Maternal separation } \\
\text { and stress }\end{array}$ & $\begin{array}{l}\text { Social anxiety and } \\
\text { recognition and stress } \\
\text { resilience }\end{array}$ & Franklin et al. 2011 [43] \\
$\begin{array}{ll}\text { Traumatic paternal } \\
\text { stress (odorant) }\end{array}$ & $\begin{array}{l}\text { Behavioral and neural } \\
\text { metabolic responses }\end{array}$ & Dias et al. 2014 [44] \\
$\begin{array}{l}\text { Gestational restraint } \\
\text { and forced swimming }\end{array}$ & $\begin{array}{l}\text { Preterm birth and } \\
\text { prenatal growth and } \\
\text { behavior }\end{array}$ & Yao et al. 2014 [1] \\
&
\end{tabular}


and decreased brain development of early postnatal offspring.

This is the first study to suggest ancestral stress can influence transgenerational preterm birth risk. Preterm birth in humans is linked to a number of postnatal abnormalities [48]. There has been a dramatic increase in preterm birth rates in recent years. Although there have been a number of proposed factors for this rise in preterm births, the current study of Yao and colleagues [1] suggests ancestral gestational stress may be a component in the pathology. Although further research is needed, the concept that ancestral gestational stress may have a role in promoting transgenerational preterm birth risk is a novel component of the disease etiology to consider. Similar considerations can be proposed for early postnatal neurodevelopmental abnormalities.

\section{Conclusions}

The study of Yao and colleagues [1] supports a role of ancestral stress in the epigenetic transgenerational inheritance of disease. Although direct stress exposure of adults can influence pathologies in the individual and offspring, the multigenerational versus transgenerational inheritance characteristics of the pathology need to be considered. A direct exposure generally affects somatic tissues that will be critical for the individual's disease, but a transgenerational effect requires a transmission of epigenetic information by the germline. Often, as shown in the current study [1], the transgenerational disease and pathology is distinct and/or has greater frequency than the direct exposure pathology [5]. The ability of stress to promote the epigenetic transgenerational inheritance of disease has now been shown in several different laboratories and animal model systems (Table 2).

A variety of environmental factors promote the epigenetic transgenerational inheritance of disease (Table 1). The observation that environmental stress can also promote transgenerational pathologies suggests ancestral stress conditions may be a significant factor in our own disease and what we pass down to our grandchildren. Several studies have considered the multigenerational impacts of stress on future generations, including World War 2 holocaust survivors' offspring [49] and traumatic stress generational effects in several African countries [50,51]. The concept that ancestral stress, particularly during gestation, may influence disease etiology for generations to come is an important aspect to consider in regards to our environment and society. This is a novel concept that will need to be seriously considered in our future health management and therapy.

\section{Competing interests}

The author declares he has no competing interests.

\section{Author information}

MKS is an Eastlick Distinguished Professor in the School of Biological Sciences and founding Director of the Center for Reproductive Biology at Washington State University, Pullman Washington, USA. His research is in the area of environmental epigenetics and reproduction (see www.skinner.wsu.edu for more information).

\section{Acknowledgements}

I thank Dr. Eric Nilsson for critical review of the manuscript and Ms. Heather Johnson for assistance in preparation of the manuscript. This research was supported by National Institutes of Health grants to MKS.

Received: 31 July 2014 Accepted: 12 August 2014

Published online: 05 September 2014

\section{References}

1. Yao Y, Robinson AM, Zucchi FCR, Robbins JC, Babenko O, Kovalchuk O, Kovalchuk I, Olson DM, Metz GAS: Ancestral exposure to stress epigenetically programs preterm birth risk and averse maternal and newborn outcomes. BMC Medicine 2014, 12:121.

2. Skinner MK, Manikkam M, Guerrero-Bosagna C: Epigenetic transgenerational actions of environmental factors in disease etiology. Trends Endocrinol Metab 2010, 21:214-222.

3. Anway MD, Cupp AS, Uzumcu M, Skinner MK: Epigenetic transgenerational actions of endocrine disruptors and male fertility. Science 2005, 308:1466-1469.

4. Manikkam M, Guerrero-Bosagna C, Tracey R, Haque MM, Skinner MK: Transgenerational actions of environmental compounds on reproductive disease and epigenetic biomarkers of ancestral exposures. PLOS One 2012, 7:e31901.

5. Skinner MK, Manikkam M, Tracey R, Nilsson E, Haque MM, Guerrero-Bosagna C: Ancestral DDT exposures promote epigenetic transgenerational inheritance of obesity. BMC Medicine 2013, 11:228.

6. Dunn GA, Bale TL: Maternal high-fat diet effects on third-generation female body size via the paternal lineage. Endocrinology 2011, 152:2228-2236.

7. Zheng X, Chen L, Li M, Lou Q, Xia H, Wang P, Li T, Liu H, Luo L: Transgenerational variations in DNA methylation induced by drought stress in two rice varieties with distinguished difference to drought resistance. PLoS One 2013, 8:e80253.

8. Norouzitallab P, Baruah K, Vandegehuchte M, Van Stappen G, Catania F, Vanden Bussche J, Vanhaecke L, Sorgeloos P, Bossier P: Environmental heat stress induces epigenetic transgenerational inheritance of robustness in parthenogenetic Artemia model. FASEB J 2014, 28:3552-3563.

9. Pembrey M, Saffery R, Bygren LO: Human transgenerational responses to early-life experience: potential impact on development, health and biomedical research. J Med Genet 2014, 51:563-572.

10. Skinner MK: Environmental epigenetic transgenerational inheritance and somatic epigenetic mitotic stability. Epigenetics 2011, 6:838-842.

11. Skinner MK, Guerrero-Bosagna C, Haque MM, Koop JAH, Knutie SA, Clayton $\mathrm{DH}$ : Role of epigenetics in the speciation and evolution of Darwin's finches. Genome Biol Evol 2014, 6:1972-1989.

12. Anway MD, Leathers C, Skinner MK: Endocrine disruptor vinclozolin induced epigenetic transgenerational adult-onset disease. Endocrinology 2006, 147:5515-5523.

13. Skinner MK, Anway MD, Savenkova MI, Gore AC, Crews D: Transgenerational epigenetic programming of the brain transcriptome and anxiety behavior. PLoS One 2008, 3:e3745

14. Nilsson EE, Anway MD, Stanfield J, Skinner MK: Transgenerational epigenetic effects of the endocrine disruptor vinclozolin on pregnancies and female adult onset disease. Reproduction 2008, 135:713-721.

15. Manikkam M, Haque MM, Guerrero-Bosagna C, Nilsson E, Skinner M: Pesticide methoxychlor promotes the epigenetic transgenerational inheritance of adult onset disease through the female germline. PLoS One 2014, 9:e102091.

16. Manikkam M, Tracey R, Guerrero-Bosagna C, Skinner M: Pesticide and insect repellent mixture (permethrin and DEET) induces epigenetic transgenerational inheritance of disease and sperm epimutations. Reprod Toxicol 2012, 34:708-719.

17. Manikkam M, Tracey R, Guerrero-Bosagna C, Skinner MK: Dioxin (TCDD) induces epigenetic transgenerational inheritance of adult onset disease and sperm epimutations. PLoS One 2012, 7:e46249. 
18. Bruner-Tran KL, Osteen KG: Developmental exposure to TCDD reduces fertility and negatively affects pregnancy outcomes across multiple generations. Reprod Toxicol 2011, 31:344-350.

19. Manikkam M, Tracey R, Guerrero-Bosagna C, Skinner M: Plastics derived endocrine disruptors (BPA, DEHP and DBP) induce epigenetic transgenerational inheritance of adult-onset disease and sperm epimutations. PLoS One 2013, 8:e55387.

20. Tracey R, Manikkam M, Guerrero-Bosagna C, Skinner M: Hydrocarbon (jet fuel JP-8) induces epigenetic transgenerational inheritance of adultonset disease and sperm epimutations. Reprod Toxicol 2013, 36:104-116.

21. Nilsson E, Larsen G, Manikkam M, Guerrero-Bosagna C, Savenkova M, Skinner M: Environmentally induced epigenetic transgenerational inheritance of ovarian disease. PLoS One 2012, 7:e36129.

22. Doyle TJ, Bowman JL, Windell VL, McLean DJ, Kim KH: Transgenerational effects of di-(2-ethylhexyl) phthalate on testicular germ cell associations and spermatogonial stem cells in mice. Biol Reprod 2013, 88:112.

23. Chamorro-Garcia R, Sahu M, Abbey RJ, Laude J, Pham N, Blumberg B: Transgenerational inheritance of increased fat depot size, stem cell reprogramming, and hepatic steatosis elicited by prenatal exposure to the obesogen tributyltin in mice. Environ Health Perspect 2013, 121:359-366.

24. Wolstenholme JT, Edwards M, Shetty SR, Gatewood JD, Taylor JA, Rissman EF, Connelly JJ: Gestational exposure to bisphenol A produces transgenerational changes in behaviors and gene expression. Endocrinology 2012, 153:3828-3838.

25. Salian S, Doshi T, Vanage G: Perinatal exposure of rats to bisphenol A affects the fertility of male offspring. Life Sci 2009, 85:742-752.

26. Bygren LO, Tinghog P, Carstensen J, Edvinsson S, Kaati G, Pembrey ME, Sjostrom M: Change in paternal grandmothers' early food supply influenced cardiovascular mortality of the female grandchildren. BMC Genet 2014, 15:12.

27. Padmanabhan $N$, Watson ED: Lessons from the one-carbon metabolism: passing it along to the next generation. Reprod Biomed Online 2013, 27:637-643.

28. Suter $L$, Widmer A: Environmental heat and salt stress induce transgenerational phenotypic changes in Arabidopsis thaliana. PLoS One 2013, 8:e60364.

29. Wei Y, Yang CR, Wei YP, Zhao ZA, Hou Y, Schatten H, Sun QY: Paternally induced transgenerational inheritance of susceptibility to diabetes in mammals. Proc Natl Acad Sci U S A 2014, 111:1873-1878.

30. Rehan VK, Liu J, Sakurai R, Torday JS: Perinatal nicotine-induced transgenerational asthma. Am J Physiol Lung Cell Mol Physiol 2013, 305:L501-L507.

31. Govorko D, Bekdash RA, Zhang C, Sarkar DK: Male germline transmits fetal alcohol adverse effect on hypothalamic proopiomelanocortin gene across generations. Biol Psychiatry 2012, 72:378-388

32. Skinner MK: What is an epigenetic transgenerational phenotype? F3 or F2. Reprod Toxicol 2008, 25:2-6

33. Kaneda M: Genomic imprinting in mammals-epigenetic parental memories. Differentiation 2011, 82:51-56.

34. Guerrero-Bosagna C, Settles M, Lucker B, Skinner M: Epigenetic transgenerational actions of vinclozolin on promoter regions of the sperm epigenome. PLoS One 2010, 5:e13100.

35. Gapp K, Jawaid A, Sarkies P, Bohacek J, Pelczar P, Prados J, Farinelli L, Miska E, Mansuy IM: Implication of sperm RNAs in transgenerational inheritance of the effects of early trauma in mice. Nat Neurosci 2014, 17:667-669.

36. Kelly WG: Transgenerational epigenetics in the germline cycle of Caenorhabditis elegans. Epigenetics Chromatin 2014, 7:6.

37. Seisenberger S, Peat JR, Hore TA, Santos F, Dean W, Reik W: Reprogramming DNA methylation in the mammalian life cycle: building and breaking epigenetic barriers. Philos Trans R Soc Lond B Biol Sci 2013, 368:20110330.

38. Gapp K, von Ziegler L, Tweedie-Cullen RY, Mansuy IM: Early life epigenetic programming and transmission of stress-induced traits in mammals: how and when can environmental factors influence traits and their transgenerational inheritance? Bioessays 2014, 36:491-502

39. Suderman M, McGowan PO, Sasaki A, Huang TC, Hallett MT, Meaney MJ, Turecki G, Szyf M: Conserved epigenetic sensitivity to early life experience in the rat and human hippocampus. Proc Natl Acad Sci U S A 2012, 109:17266-17272
40. Dietz DM, Laplant Q, Watts EL, Hodes GE, Russo SJ, Feng J, Oosting RS, Vialou V, Nestler EJ: Paternal transmission of stress-induced pathologies. Biol Psychiatry 2011, 70:408-414

41. Morgan CP, Bale TL: Early prenatal stress epigenetically programs dysmasculinization in second-generation offspring via the paternal lineage. J Neurosci 2011, 31:11748-11755.

42. Ward ID, Zucchi FC, Robbins JC, Falkenberg EA, Olson DM, Benzies K, Metz GA: Transgenerational programming of maternal behaviour by prenatal stress. BMC Pregnancy Childbirth 2013, 13:S9.

43. Franklin TB, Linder N, Russig $H$, Thony B, Mansuy IM: Influence of early stress on social abilities and serotonergic functions across generations in mice. PLoS One 2011, 6:e21842.

44. Dias BG, Ressler KJ: Parental olfactory experience influences behavior and neural structure in subsequent generations. Nat Neurosci 2014, 17:89-96.

45. Matthews SG, Phillips DI: Transgenerational inheritance of stress pathology. Exp Neurol 2012, 233:95-101.

46. Crews D, Gillette R, Scarpino SV, Manikkam M, Savenkova MI, Skinner MK Epigenetic transgenerational inheritance of altered stress responses. Proc Natl Acad Sci U S A 2012, 109:9143-9148.

47. Gillette R, Miller-Crews I, Nilsson EE, Skinner MK, Gore AC, Crews D: Sexually dimorphic effects of ancestral exposure to vinclozolin on stress reactivity in rats. Endocrinology 2014, [Epub ahead of print].

48. lams JD, Donovan EF: Spontaneous late preterm births: what can be done to improve outcomes? Semin Perinatol 2011, 35:309-313.

49. Dekel S, Mandl C, Solomon Z: Is the Holocaust implicated in posttraumatic growth in second-generation Holocaust survivors? A prospective study. J Trauma Stress 2013, 26:530-533.

50. Saile R, Ertl V, Neuner F, Catani C: Does war contribute to family violence against children? Findings from a two-generational multi-informant study in Northern Uganda. Child Abuse Negl 2014, 38:135-146.

51. Roth M, Neuner F, Elbert T: Transgenerational consequences of PTSD: risk factors for the mental health of children whose mothers have been exposed to the Rwandan genocide. Int J Ment Health Syst 2014, 8:12.

\section{doi:10.1186/s12916-014-0153-y}

Cite this article as: Skinner: Environmental stress and epigenetic transgenerational inheritance. BMC Medicine 2014 12:153.

\section{Submit your next manuscript to BioMed Central and take full advantage of:}

- Convenient online submission

- Thorough peer review

- No space constraints or color figure charges

- Immediate publication on acceptance

- Inclusion in PubMed, CAS, Scopus and Google Scholar

- Research which is freely available for redistribution 